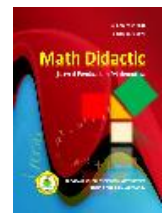

MATH DIDACTIC: JURNAL PENDIDIKAN MATEMATIKA

Volume 4 Nomor 2, Mei - Agustus 2018, halaman 121 - 127

Tersedia Daring pada http://jurnal.stkipbjm.ac.id/index.php/math

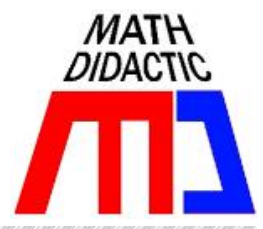

\title{
KEEFEKTIFAN STRATEGI KONFLIK KOGNITIF DITINJAU DARI KEMAMPUAN BERPIKIR KRITIS
}

\section{THE EFFECTIVENESS COGNITIVE CONFLICT STRATEGY IN TERMS OF CRITICAL THINKING ABILITY}

\author{
Inggrid Marlissa, Kamariah \\ Universitas Musamus Merauke \\ Inggrid_fkip@unmus.ac.id, kamariah@unmus.ac.id
}

\begin{abstract}
Abstrak: Tujuan penelitian ini adalah untuk mendeskripsikan keefektifan pembelajaran strategi konflik kognitif dalam pembelajaran yang ditinjau dari kemampuan berpikir kritis. Penelitian ini merupakan penelitian eksperimen yang populasinya mencakup seluruh siswa kelas X MIPA SMA Negeri 2 Merauke yang terdiri dari enam kelas. Dari enam kelas tersebut, kelas X MIPA 1 dipilih secara acak sebagai sampel. Teknik pengumpulan data dalam penelitian ini adalah teknik tes dengan instrumen untuk mengumpulkan data meliputi soal tes kemampuan berpikir kritis. Untuk melihat keefektifan dari strategi konflik kognitif dalam pembelajaran menggunakan uji univariat. Uji univariat yang digunakan adalah uji $\mathrm{t}$ satu sampel. Hasil penelitian pada taraf $5 \%$ menunjukkan bahwa pembelajaran dengan strategi konflik kognitif efektif ditinjau dari kemampuan berpikir kritis dan tingkat kemampuan berpikir kritis berada pada kategori sedang.
\end{abstract}

Kata Kunci: strattegi konflik kognitif, kemampuan berpikir kritis

\begin{abstract}
The purpose of this study was to describe the effectiveness of cognitive conflict strategy learning in terms of critical thinking skills. This study was a experimental research whose population consisted of all $10^{\text {th }}$ graders in State Senior High School 2 of Merauke which includes six classes. Out of the six classes, one groups of students was randomly selected to class X MIPA 1. The data collecting techniques were a test whereas the instrument used to the collect the data consisted of critical thinking skills test. To see the effectiveness of cognitive conflict strategy learning using univariate tests. The univariate test used is one sample t test. The results of the study, using significance level 5\%, showed that the cognitive conflict strategy learning is effective in terms of critical thinking skills and the level of critical thinking ability is in the medium category.
\end{abstract}

Keywords: cognitive conflict strategy, critical thinking skills.

Cara sitasi: Rosyadi, A.A.P. (2018). Pengembangan Modul Berbasis Riset pada Matakuliah Kalkulus untuk Meningkatkan Kreatifitas Mahasiswa. Math Didactic: Jurnal Pendidikan Matematika, 4(2), 121-127.

Standar kompetensi lulusan menyebutkan bahwa kompetensi yang harus dimiliki oleh peserta didik setelah mempelajari matematika yaitu memiliki kemampuan berpikir logis, analitis, sistematis, kritis, dan kreatif serta mempunyai kemampuan bekerjasama (Permendiknas Nomor 23 Tahun
2006). Kompetensi lain yang diharapkan dimiliki oleh peserta didik yaitu memiliki sikap menghargai kegunaan matematika dalam kehidupan, yaitu memiliki rasa ingin tahu, perhatian, dan minat dalam mempelajari matematika, serta sikap ulet dan percaya diri dalam pemecahan masalah. 
Permendiknas Nomor 22 Tahun 2006 menjelaskana bahwa mata pelajaran Matematika perlu diberikan kepada semua peserta didik mulai dari sekolah dasar untuk membekali peserta didik ke pendidikan selanjutnya. Kompetensi tersebut diperlukan agar peserta didik dapat memiliki kemampuan memperoleh, mengelola, dan memanfaatkan informasi untuk bertahan hidup pada keadaan yang selalu berubah, tidak pasti, dan kompetitif.

Berdasarkan hasil wawancara dengan guru mata pelajaran matematika, dalam pembelajaran matematika masih dijumpai guru yang mengeluhkan rendahnya kemampuan peserta didik, dan berdampak pada rendahnya kualitas proses dan prestasi belajar matematika peserta didik. Menurut Soedjadi (2000, hal. 179), guru matematika perlu merenungi kembali sebenarnya untuk apa matematika diajarkan kepada siswa, tentu bukan untuk mengetahui semua matematika yang ada atau sebanyak mungkin mengetahui matematika. Jawaban yang harus menjadi perhatian adalah matematika diberikan kepada siswa untuk membantu siswa agar tertata nalarnya, terbentuk kepribadiannya serta terampil menggunakan matematika dan penalarannya dalam kehidupannya kelak.

Hadi (2005, hal. 11) menyatakan bahwa proses pembelajaran matematika selama ini yang terjadi belum sesuai dengan yang diharapkan. Ciri praktik pendidikan selama ini adalah pembelajaran berpusat pada guru. Guru menyampaikan pelajaran dengan menggunakan metode ceremah atau ekspositori, sementara siswa mencatatnya pada buku catatan. Dominasi guru dalam proses pembelajaran menyebabkan kecenderungan siswa lebih bersifat pasif sehingga mereka lebih banyak menunggu sajian guru daripada mencari dan menemukan sendiri pengetahuan, keterampilan atau sikap yang mereka butuhkan. Pembelajaran matematika seperti ini menyebabkan siswa mengalami kesulitan untuk memahami materi pelajaran yang abstrak. Kondisi ini mengakibatkan mata pelajaran matematika masih dipandang sebagai mata pelajaran yang sulit oleh para pelajar maupun masyarakat umumnya (Muijs \& Reynalds, 2005, hal. 212).

Salah satu kemampuan yang harus dimiliki siswa adalah berpikir kritis. Akan tetapi Pada kenyataannya, berdasarkan observasi di sekolah ketika siswa diminta oleh guru untuk menyelesaikan suatu permasalahan matematika, mereka cepat dalam merespon atau menyelesaikan permasalahan tersebut, tetapi mereka belum bisa memberikan argumen atau alasan yang tepat untuk mempertanggung-jawabkan jawaban mereka. Fakta lain juga menyebutkan bahwa hasil kajian PISA yang menunjukkan kemampuan berpikir kritis siswa Indonesia masih perlu ditingkatkan. Hal ini ditunjukkan oleh grafik yang dipaparkan oleh Stacey dalam Konferensi Nasional Pendidikan Matematika 5 (KNPM 5) bahwa untuk matematika, Indonesia mengalami penurunan dari tahun 2000 sampai tahun 2009. Dalam grafik Distribution of Mathematical Literacy juga menunjukkan bahwa hampir $80 \%$ siswa Indonesia masih berada di level 2 (level terendah).

PISA mengukur kompetensi siswa dalam 3 aspek utama (OECD, 2004, hal. 25) yaitu isi (struktur) materi yang diperoleh siswa, proses yang dikerjakan siswa dalam menyajikan argumentasi dan respon siswa di saat mereka dihadapkan pada permasalahan dalam kehidupan sehari-hari (pengambilan keputusan) yang dapat diselesaikan dengan model matematika dan perhitungan matematis. Tiga aspek tersebut juga berkaitan dengan 
kemampuan berpikir kritis karena dalam menyelesaikan soal-soal PISA, siswa menyajikan argumen atau alasan atas proses penyelesaian yang mereka kerjakan, dimana proses tersebut akan menghasilkan atau berdampak pada keputusan atau hasil akhir. Dengan hasil yang telah dipaparkan di atas, maka kita dapat menyimpulkan bahwa kemampuan berpikir kritis siswa Indonesia dalam menyelesaikan permasalahan matematika masih perlu untuk ditingkatkan.

Untuk meningkatkan hal tersebut, perlu diterapkan strategi pembelajaran yang sesuai dan salah satunya adalah strategi konflik kognitif. Pembelajaran yang menggunakan konflik kognitif telah dilakukan sejak tahun 1990-an, sebagaimana diungkap oleh Baser (2006, hal. 99) bahwa: Since 1990's, cognitive conflict based instructions have been extensively used in science education. Several studies concluded that that cognitive conflict has an important/positive effect on conceptual change. (Sejak 1990-an, pembelajaran berdasarkan konflik kognitif telah banyak digunakan dalam pendidikan sains. Beberapa penelitian menyimpulkan bahwa bahwa konflik kognitif memiliki/efek positif penting pada perubahan konseptual).

Teori Piaget (Ismaimuza, 2010, hal. 2) mengatakan bahwa struktur kognitif yang dimiliki selalu berinteraksi dengan lingkungannya dengan cara asimilasi dan akomodasi. Jika asimilasi dan akomodasi terjadi secara bebas atau tanpa konflik, maka struktur kognitif dikatakan berada pada keadaan seimbang (equilibrium) dengan lingkungannya. Namun, jika terjadi konflik maka seseorang berada pada keadaan tidak seimbang (disequilibrium). Hal ini terjadi karena skema yang masuk tidak sama dengan struktur (skema) kognitif yang dimilikinya. Ketika seorang berada pada keadaan disequilibrium, orang tersebut akan merespon keadaan ini, dan berupaya mengingat, memberdayakan konsep yang dimilikinya untuk mencari equilibrium baru dengan lingkungannya. Melalui metakognisi, bertanya pada teman yang tidak mengalami konflik, atau scaffolding yang diberikan guru maka siswa dapat keluar dari konflik. Jadi, konflik kognitif merupakan syarat awal atau stimulus dalam memperoleh keseimbangan (equilibrium) baru. Tingkat keseimbangan (equilibrium) baru ini lebih tinggi tingkatannya dari keseimbangan (equilibrium) sebelumnya.

Yunus (2008, hal. 31) mengemukakan perbedaan strategi konflik kognitif dengan strategi dengan strategi konvensional adalah adanya pertanyaan dan contoh tandingan yang sifatnya menantang siswa untuk berpikir sehingga siswa dapat memperbaiki sendiri pemahamannya. Sedangkan strategi pembelajaran dengan strategi konvensional adalah strategi pembelajaran yang menekankan kepada proses penyampaian materi secara lisan dari seorang guru kepada sekelompok siswa dengan maksud agar siswa dapat menguasai materi pelajaran secara optimal. Berdasarkan strategi ini, tugas-tugas diberikan kepada siswa pada akhir pelajaran.

Penelitian yang telah dilakukan oleh Tayeb, Muslimin, \& Mansyur (2015, hal. 45) menyimpulkan bahwa pembelajaran dengan menggunakan strategi konflik kognitif dapat mempengaruhi perubahan konsep siswa. Selanjutnya, salah satu kesimpulan penelitian oleh Handhika, Kurniadi, \& Muda (2014, hal 12) adalah penggunaan media pembelajaran bermuatan konflik kognitif yang telah dikembangkan mampu mereduksi miskonsepsi mahasiswa pada mata kuliah Fisika Dasar. 


\section{Metode Penelitian}

Jenis penelitian yang digunakan dalam penelitian ini adalah penelitian eksperimen. Penelitian dilaksanakan pada bulan Juli 2017 sampai dengan bulan September 2017 di SMA Negeri 2 Merauke dengan Subjek penelitian yaitu siswa kelas X MIPA 1. Teknik pengumpulan data dalam penelitian ini adalah teknik tes dengan instrumen untuk mengumpulkan data meliputi soal tes kemampuan berpikir kritis. Teknik analisis data yang digunakan adalah sebagai berikut: Analisis Deskriptif.

Data penelitian yang akan dianalisis dalam penelitian ini meliputi skor kemampuan berpikir kritis. Data yang disajikan meliputi rata-rata, standar deviasi, nilai minimum serta nilai maksimum yang diperoleh siswa.

Selain itu, sebaran skor akan dikelompokkan berdasarkan yang digunakan oleh Masrurotullalily, Hobri, dan Suharto (2013, hal 133) yaitu tiga tingkatan berupa:

Tabel 1. Klasifikasi Tingkat Kemampuan Berpikir Kritis Matematis Siswa

\begin{tabular}{|c|c|c|}
\hline \multicolumn{2}{|c|}{ Rentang Nilai } & Tingkat Kemampuan \\
\hline $0<N$ & $<60$ & Rendah \\
\hline $60<N$ & $\leq 75$ & Sedang \\
\hline $75<N$ & $\leq 100$ & Tinggi \\
\hline
\end{tabular}

(Dengan NKBK = Nilai Kemampuan Berpikir Kritis)

Untuk mengukur besar persentase kemampuan siswa dalam tiap-tiap indikator kemampuan berpikir kritis matematis digunakan rumus seperti berikut:

$$
P_{i}=\frac{n_{i}}{N} \times 100 \%
$$

Dengan keterangan:

$P_{i}=$ Persentase siswa pada setiap kemampuan berpikir kritis matematis

$n_{i}=$ Banyaknya Siswa pada setiap kemampuan berpikir kritis matematis
$N=$ Jumlah total siswa yang mengikuti tes kemampuan berpikir kritis matematis

Selanjutnya, untuk melihat keefektifan dari pembelajaran strategi konflik kognitif menggunakan uji univariat. Uji yang digunakan adalah uji t satu sampel.

Sebelum pengujian hipotesis dilakukan terlebih dulu uji asumsi yaitu uji normalitas dan uji homogenitas. Uji normalitas yang digunakan menggunakan uji KolmogorovSmirnov dengan program SPSS. Kriteria keputusan dalam pengujian ini adalah jika nilai probabbilitas lebih besar dari 0,05 maka dapat disimpulkan berasal dari populasi yang berdistribusi normal. Sedangkan uji homogenitas dapat di dilihat dari hasil Levene's test pada program SPSS. Jika nilai signifikansi Levene's test lebih besar dari taraf signifikansi 0,05 maka dapat dikatakan bahwa varians masing-masing variabel dependen adalah homogen.

Apabila kedua asumsi tersebut terpenuhi maka akan dilakukan uji perbedaan rata-rata terhadap kemampuan berpikir kritis. Untuk menguji beda rata-rata akan menggunakan bantuan program SPSS 21 dengan menu Analyze - Compare Means Independent-samples T-test.

\section{Hasil Penelitian dan Pembahasan}

\section{Hasil}

Data kemampuan berpikir kritis diperoleh dengan memberikan tes pretest dan postest dapat dilihat dalam sajian tabel berikut. 
Tabel 2.

Statistik Deskriptif Kemampuan Berpikir Kritis

\begin{tabular}{|c|c|c|}
\hline \multirow{2}{*}{ Nilai } & \multicolumn{2}{|c|}{$\begin{array}{c}\text { Kelas } \\
\text { Eksperimen }\end{array}$} \\
\cline { 2 - 3 } & Pretest & Posttest \\
\hline Rata-rata & 43,32 & 63,87 \\
\hline StandarDeviasi & 17,68 & 10,61 \\
\hline Skor terendah & 25,00 & 26,25 \\
\hline Skor tertinggi & 73,75 & 90,00 \\
\hline
\end{tabular}

Data pada tabel diatas menunjukkan bahwa kelas eksperimen mengalami peningkatan rata-rata sebesar 20,55. Peningkatan kemampuan berpikir kritis dapat dilihat melalui persentase masing-masing indikator kemampuan berpikir kritis yang disajikan pada tabel berikut.

Tabel 3.

Persentase kemampuan berpikir kritis tiap Aspek

\begin{tabular}{|c|l|c|c|}
\hline No & \multicolumn{1}{|c|}{ Indikator } & Pretest & Posttest \\
\hline 1 & $\begin{array}{l}\text { Menentukan konsep } \\
\text { dalam penyelesaian } \\
\text { masalah }\end{array}$ & 47,34 & 69,84 \\
\hline 2 & $\begin{array}{l}\text { Merumuskan cara dalam } \\
\text { menyelesaikan masalah }\end{array}$ & 45,47 & 64,69 \\
\hline 3 & $\begin{array}{l}\text { Memberikan argumen } \\
\text { dalam menyelesaikan } \\
\text { masalah }\end{array}$ & 41,09 & 60,63 \\
\hline 4 & $\begin{array}{l}\text { Mengevaluasi } \\
\text { penyelesaian masalah }\end{array}$ & 39,38 & 60,31 \\
\hline
\end{tabular}

Selain itu, data pretest dan posttest kemudian dikonversi dalam kategori rendah, sedang dan tinggi. Hasil pengelompokan bisa dilihat pada tabel berikut.

Tabel 4

Kategori Kemampuan Berpikir Kritis Matematis

\begin{tabular}{|c|c|c|c|c|}
\hline \multirow{2}{*}{$\begin{array}{c}\text { Tingkat } \\
\text { Kemampuan } \\
\text { Berpikir }\end{array}$} & \multicolumn{4}{|c|}{ Banyak Siswa } \\
\hline & \multicolumn{2}{|c|}{ Pretest } & \multicolumn{2}{|c|}{ Posttest } \\
\hline Rendah & 29 & $90,63 \%$ & 9 & $28,13 \%$ \\
\hline Sedang & 3 & $9,37 \%$ & 16 & $50 \%$ \\
\hline Tinggi & 0 & $0 \%$ & 7 & $21,87 \%$ \\
\hline
\end{tabular}

Berdasarkan tabel di atas, dapat dilihat bahwa pada saat pretest sebagian besar siswa berada pada kategori rendah bahkan tidak ada siswa yang berada pada kategori tinggi. Sedangkan setelah posttest sebanyak 50\% siswa berada pada kategori sedang.

Selanjutnya, untuk mengetahui keefektifan pembelajaran matematika ditinjau dari variabel kemampuan berpikir kritis akan dilakukan dengan menggunakan uji t satu sampel. Uji t satu sampel bisa dilakukan apabila sebaran data yang akan diuji memenuhi asumsi normalitas. Oleh karena itu berikut ini dilakukan uji asumsi terlebih dahulu sebelum melakukan uji hipotesis.Uji asumsi yang dimaksud adalah uji normalitas univariat.

Uji asumsi normalitas pada data postes dapat dilihat dari hasil signifikansi kolmogorov-smirrnov dengan bantuan program SPSS 21.0. Berikut ini adalah tabel output hasil pengujian kenormalan dari data pretest.

Tabel 5.

Hasil Uji Asumsi Normalitas Univariat

\begin{tabular}{|l|l|c|l|l|}
\hline Variabel & Kelas & $\begin{array}{l}\text { Kolmogorov- } \\
\text { Smirnov Z }\end{array}$ & Sig. & Ket \\
\hline $\begin{array}{l}\text { Kem. } \\
\begin{array}{l}\text { Berpikir } \\
\text { Kritis }\end{array}\end{array}$ & Pretest & 0,928 & 0,356 & Normal \\
\cline { 2 - 5 } & Posttest & 0,925 & 0,359 & Normal \\
\hline
\end{tabular}

Berdasarkan tabel 5 di atas, terlihat bahwa masing-masing variabel dependen pada kedua kelas memiliki nilai signifikansi lebih besar dari 0,05 sehingga asumsi normalitas terpenuhi. Selanjutnya dilakukan uji hipotesis karena telah memenuhi asumsi normalitas univariat.

Hasil perhitungan dilakukan dengan menggunakan program SPSS pada tabel (Paired Samples Correlations) menunjukkan besarnya korelasi antara nilai pretest dan posttest yaitu sebesar 0,456 dengan taraf signifikansi 0,009 yang artinya ada peningkatan kemampuan berpikir kritis matematis siswa. Selain itu, pada tabel (Paired Samples Test) menunjukkan nilai $t_{\text {hitung }}$ sebesar 
-7,652 dengan tingkat Sig (2-tailed) sebesar 0,001 yang artinya ada peningkatan kemampuan berpikir kritis matematis siswa.

Karena ada peningkatan kemampuan berpikir kritis matematis siswa sebelum dan sesudah diberi tindakan maka dengan demikian dapat ditarik kesimpulan bahwa ada pembelajaran dengan strategi konflik kognitif efektif ditinjau dari kemampuan berpikir kritis matematis siswa.

\section{Pembahasan}

Hasil pengujian hipotesis menunjukkan bahwa strategi konflik kognitif efektif ditinjau dari kemampuan berpikir kritis matematis siswa. Hal ini sejalan dengan penelitian sebelumnya yang dilakukan oleh Basir dan Karmila (2015, hal. 92) hasilnya menunjukkan bahwa penerapan strategi konflik kognitif dengan materi pokok dimensi tiga di kelas X SMA Negeri 16 Makassar efektif terhadap pemahaman konsep siswa.

Pada saat proses pembelajaran berlangsung, dibentuk kelompok-kelompok belajar. Besar kemungkinan dengan adanya kelompok-kelompok tersebut maka pembelajaran dengan strategi konflik kognitif menjadi efektif. Sebagaimana pernyataan yang diungkapkan oleh de Walle (2008, hal. 4-5) bahwa diskusi antarsiswa akan dapat mengeksplorasi ide-ide matematik dari berbagai sudut pandang siswa sehingga menambah pemahaman matematika.

Pembelajaran dengan strategi konflik kognitif memberikan kemudahan bagi siswa dalam mempelajari konsep-konsep dasar matematika, melatih siswa berpikir kritis dan kreatif serta meningkatkan aktivitas belajar siswa. Hal ini sejalan dengan teori belajar bermakna dari Ausubel, belajar bermakna terjadi bila pelajar mencoba menghubungkan fenomena baru kedalam struktur pengetahuan mereka. Ini terjadi melalui belajar konsep, dan perubahan konsep yang ada akan mengakibatkan pertumbuhan dan perubahan struktur konsep yang telah dipunyai siswa.

Selain itu, langkah awal dalam mengembangkan kemampuan berpikir kritis matematis siswa adalah mengidentifikasi masalah dengan baik, mencari tahu apa masalah yang sebenarnya, dan bagaimana membuktikannya. Penting sekali kemampuan berpikir kritis haruslah dilatih secara terus menerus. Hal ini sejalan dengan Bonnie dan Potts (2003) secara singkat dapat disimpulkan bahwa beberapa "ciri khas" pembelajaran berpikir kritis meliputi : (1) Meningkatkan interaksi antar siswa, (2) Dengan mengajukan pertanyaan open-ended, (3) Memberikan waktu yang memadai kepada siswa untuk memberikan refleksi terhadap pertanyaan yang diajukan atau masalah-masalah yang diberikan, dan (4) Teaching for transfer (Mengajar untuk dapat menggunakan kemampuan yang baru saja diperoleh terhadap situasi-situasi lain dan terhadap pengalaman sendiri yang para siswa miliki).

Hasil penelitian ini menunjukkan bahwa indikator menentukan konsep dalam penyelesaian masalah memiliki persentase yang tinggi yaitu $69,84 \%$ sedangkan indikator mengevaluasi penyelesaian masalah memiliki persentase yang rendah yaitu $60,31 \%$. Selain itu, kategori kemampuan berpikir kritis matematis siswa sebanyak $50 \%$ berada pada kategori sedang.

\section{Simpulan dan Saran}

\section{Simpulan}

Berdasarkan hasil penelitian dan pembahasan maka diperoleh kesimpulan bahwa 
pembelajaran dengan strategi konflik kognitif efektif ditinjau dari kemampuan berpikir kritis matematis siswa.

\section{Saran}

Berdasarkan hasil serta temuan penelitian, dan dengan memperhatikan keterbatasan penelitian, saran yang dapat disampaikan adalah Dalam menerapkan strategi pembelajaran, guru hendaknya menggunakan berbagai sumber agar proses pembelajaran berlangsung dengan baik dan lancar serta dapat merancang pembelajaran yang lebih bervariasi.

\section{Daftar Pustaka}

Baser, M. (2006). Fostering conceptual change by cognitive conflict based instruction on students understanding. European Journal of Mathematics Science and Technology Education, 2, 96-114

Basir, F dan Karmila. (2015). Keefektifan Strategi Konflik Kognitif terhadap Pemahaman Konsep Matematika Siswa. Prosiding, Seminar Nasional yang diselenggarakan oleh Universitas Cokroaminoto Palopo. Palopo: Universitas Cokroaminoto Palopo.

Depdiknas. (2006). Peraturan menteri pendidikan nasional RI Nomor 23 tahun 2006 tentang standar kompetensi kelulusan.

de Walle, J.A.V. (2008). Matematika sekolah dasar dan menengah (Terjemahan Suyono). Boston, MA: Pearson Education, Inc. (Buku asli diterbitkan tahun 2007)

Hadi. (2005). Pendidikan Matematika Realistic dan Implementasinya. Banjarmasin: Tulip
Handhika, J., Kurniadi, E., \& Muda, I. (2014). Pengembangan Media Pembelajaran Bermuatan Konflik Kognitif untuk Mengurangi Dugaan Miskonsepsi pada Mata Kuliah Fisika Dasar. Jurnal Materi dan Pembelajaran Fisika (JMPF), 4 (2), 8-13.

Ismaimuza, D. (2010). Pengaruh Pembelajaran Berbasis Masalah dengan Strategi Konflik Kognitif terhadap Kemampuan Berpikir Kritis Matematis dan Sikap Siswa SMP. Jurnal Pendidikan Matematika 4(1),1-9.

Masrurotullalily, Hobri, dan Suharto (2013). Analisis Kemampuan Pemecahan Masalah Matematika Keuangan berdasarkan Model Polya Siswa SMK Negeri 6 Jember. Prosiding: Kadikna

Muijs, D., \& Reynolds, D. (2005). Effective teaching evidence and practice. ( $2^{\text {nd }}$ ed.). London: SAGE Publication

OECD. (2004). OECD Principles of Corporate Governance. France: OECD Publications Service.

Soedjadi. (2000). Kiat pendidikan matematika di Indonesia. Jakarta: Raja Grasindo Persada.

Tayeb, F.A., Muslimin, \& Mansyur, J. (2015). Pengaruh Pembelajaran Menggunakan Strategi Konflik Kognitif terhadap Perubahan Konsep tentang Gerak pada Siswa Kelas X MAN Model Palu. Jurnal Pendidikan Fisika Tadulako (JPFT), 3 (1), 38-45.

Yunus, M. (2008). Perbandingan Strategi Konflik Kognitif dengan Strategi Konvensional terhadap Hasil Belajar Siswa Kelas XI IPA SMA Negeri 1 Makassar. Jurnal Chemical, 9 (2), 3036. 